\title{
Monitoring of Groundwater Chemical Composition in Areas of Crop Production
}

\author{
Joanna Fronczyk ${ }^{1}$, Mariusz Lech ${ }^{2}$, Maja Radziemska $^{3}$, Anna Sieczka ${ }^{4}$, and Zbigniew Lechowicz ${ }^{5}$
}

\begin{abstract}
The main objective of the research presented in the paper was the monitoring of contaminant indicators in the groundwater in the area of precision cultivation of winter wheat in the northern, southern and central part of Poland. On each of the experimental sites, 6 piezometers were located, from which samples for chemical analysis were taken. The following parameters were determined: $\mathrm{pH}$, electrical conductivity, nitrogen compounds, phosphates, sulphates, and heavy metals $(\mathrm{Cu}, \mathrm{Pb}, \mathrm{Zn})$.

The results obtained revealed that fertilization has impact on the level of phosphorus, which in most of the analyzed samples, according to Polish legal provisions, was characteristic of III Class of groundwater quality $\left(0.5-1.0 \mathrm{mgPO}_{4} / \mathrm{L}\right)$. The concentration of $\mathrm{NO}_{3}$ was below the highest acceptable concentration of that parameter in drinking water recommended by WHO (50 $\mathrm{mg} \mathrm{NO} / \mathrm{L}$ ). Nitrites, copper and lead concentrations did not exceed the maximum limits under Polish legal provisions for water intended for human consumption. In addition, sulphate ions had in most samples a concentration characteristic of III Class of groundwater quality (60 $250 \mathrm{MgSO}_{4} / \mathrm{L}$ ), and in samples collected at the Chociwel site - of IV Class $\left(250-300 \mathrm{mgSO}_{4} / \mathrm{L}\right)$. However, the increased levels of this parameter did not result from fertilization. The study shows that the applied precision nitrogen fertilization could influence the acceptable concentration of nitrates in groundwater, while the inadequacy of the phosphoric fertilizer to the needs of the plants could have resulted in the increased concentrations of phosphate in the analyzed groundwater samples.
\end{abstract}

Keywords - ammonium nitrate, fertilization, groundwater quality, phosphate fertilizers, precision agriculture.

\section{INTRODUCTION}

$\mathrm{T}$ HE intensification of agricultural production may cause increasing stress on the ecosystem [1]. Plant production, inter alia wheat as the third most-produced cereal in the world, is widely recognized as a branch of economy that affects the

Joanna Fronczyk ${ }^{1}$ Faculty of Civil and Environmental Engineering, Warsaw University of Life Sciences - SGGW, Nowoursynowska 159, 02-776 Warsaw, Poland

Mariusz Lech ${ }^{2}$ Faculty of Civil and Environmental Engineering, Warsaw University of Life Sciences - SGGW, Nowoursynowska 159, 02-776 Warsaw, Poland

Maja Radziemska ${ }^{3}$ Faculty of Civil and Environmental Engineering, Warsaw University of Life Sciences - SGGW, Nowoursynowska 159, 02-776 Warsaw, Poland

Anna Sieczka ${ }^{4}$ Faculty of Civil and Environmental Engineering, Warsaw University of Life Sciences - SGGW, Nowoursynowska 159, 02-776 Warsaw, Poland

Zbigniew Lechowicz ${ }^{5}$ Faculty of Civil and Environmental Engineering, Warsaw University of Life Sciences - SGGW, Nowoursynowska 159, 02-776 Warsaw, Poland environment negatively, especially due to the contamination of surface and groundwater with nutrients (nitrogen and phosphorus) and pesticides. Because of their mobility in the soil-water environment, nitrates and phosphates may primarily migrate into groundwater. This phenomenon takes place because due to their anionic form nitrates and phosphates are not retained by soil particles and thus may cause eutrophication of groundwater and surface water [2], [3]. As Sharpley et al. [4] and Ulrich et al. [5] have reported, the overenrichment of nitrogen $(\mathrm{N})$ and phosphorus $(\mathrm{P})$ are a pervasive water quality concern. According to CSO data [6], an average of $75.5 \mathrm{~kg} / \mathrm{ha}$ of nitrogen fertilizers and $24.3 \mathrm{~kg} / \mathrm{ha}$ of phosphorus was used in Poland in 2014, which resulted in the consumption of $1,098.4$ thousand tons of nitrogenous fertilizers and 341.1 thousand tons of phosphate fertilizers. In Poland, the most commonly used are nitrogenous fertilizers, among which the most popular are ammonium nitrate, urea and nitro-chalk.

Runoff from agricultural areas is considered the main source of groundwater pollution by nitrogen compounds, which in Poland may cause eutrophication of the Baltic Sea. Approx. $5 \%$ of the monitoring stations in Poland have recorded groundwater nitrate concentrations above $50 \mathrm{mg} / \mathrm{L}$, approx. $3 \%$ - a concentration between 40 and $50 \mathrm{mg} / \mathrm{L}$ and approx. $87 \%$ - a concentration below $25 \mathrm{mg} / \mathrm{L}$. Based on average annual data from all monitoring stations of surface fresh water in EU-27, approx. 86\% of the stations have recorded nitrate concentrations below $25 \mathrm{mg} / \mathrm{L}$, slightly more than $2 \%$ have shown a concentration between 40 and $50 \mathrm{mg} / \mathrm{L}$, and just over $2 \%$ have indicated a concentration greater than $50 \mathrm{mg} / \mathrm{L}$ [7]. Therefore, it is necessary to take measures aimed at reducing the concentration of nitrogen in surface water and groundwater, and to monitor the nitrogen cycle in soil and its migration in the aquifer. Limitation of nutrient losses and thus their spread into the environment is achieved through precision agriculture, which allows adjustment of the dose of fertilizer precisely to the needs of the crops. One of the possibilities to limit the migration of the nutrient in the subsoil used in the world is the application of permeable reactive barriers [8], [9]. This method utilizes the properties of various reactive materials to remove contaminants from groundwater [10]-[13].

The EU Water Directive [14] recommends the use of principles of sustainable development in the management of surface water and groundwater, and sets out a timetable of measures to ensure good quality of all waters in Europe. 


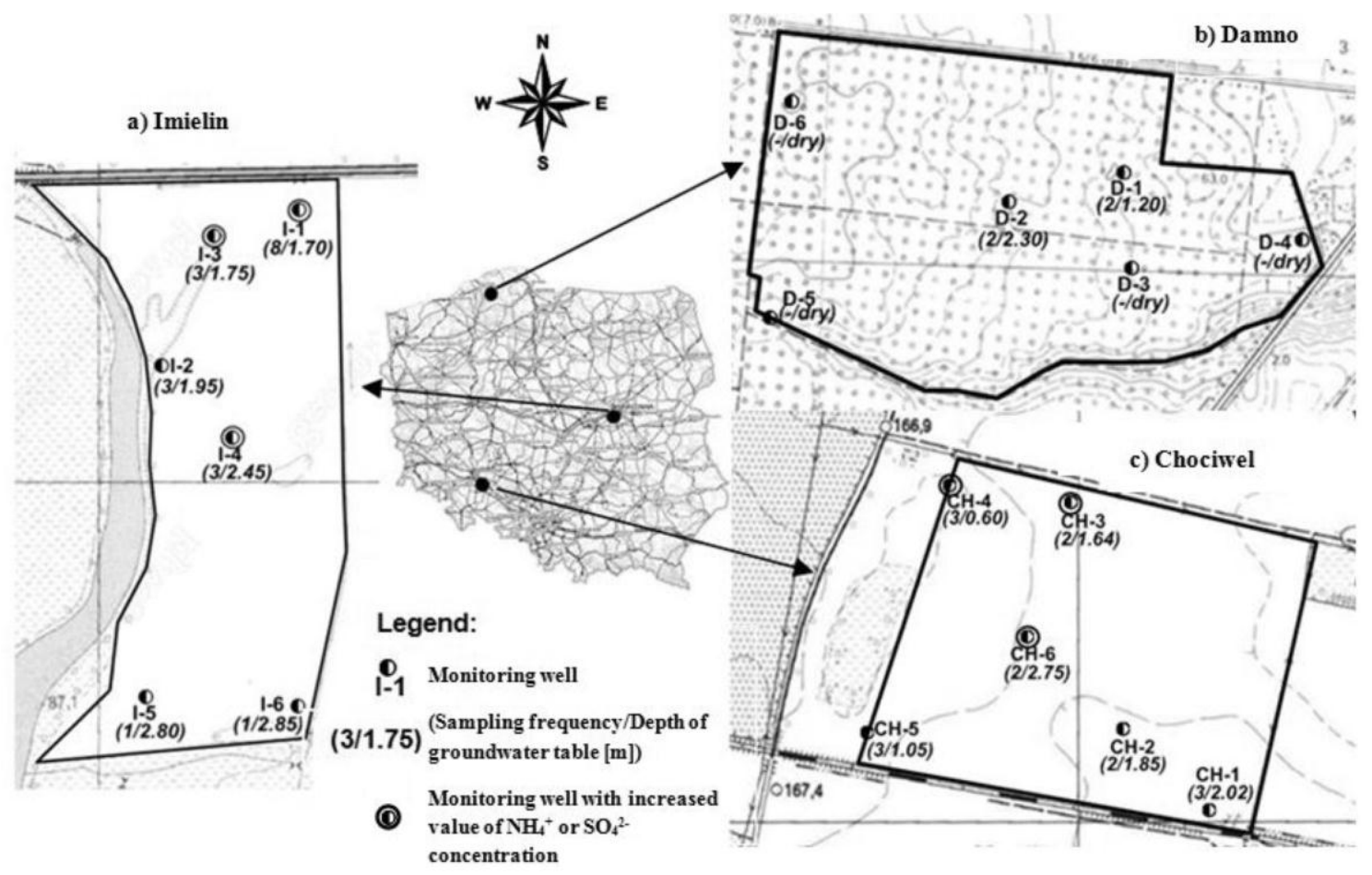

Fig. 1 Location of groundwater monitoring wells; experimental sites at a) Imielin; b) Damno; and c) Chociwel

The Council Directive 91/676/EEC [15] concerning the protection of waters against pollution caused by nitrates from agricultural sources aims at reducing water pollution and preventing such pollution through the monitoring of all types of uniform bodies of water, designation of vulnerable zones of nitrate pollution, establishing codes of good agricultural practice, and submitting the progress of implementation of the Directive every four years to the Commission.

The aim of the studies presented in the paper was the monitoring of contaminant indicators in groundwater in the area of precision cultivation of winter wheat in southern (Chociwel experimental site), northern (Damno experimental site) and central (Imielin experimental site) Poland.

\section{MATERIAL AND METHODS}

\section{A. Experimental sites}

Monitoring studies were conducted at three experimental sites located in various parts of Poland. The research was carried out in areas of crop production fertilized with the use of precision farming tools, but differing in terms of physical, geographical and climate conditions. The location of the experimental sites and the groundwater monitoring wells is shown in Fig. 1.

The Chociwel site (20 ha) is located near Wroclaw city in southern Poland. The area of the crop field is flat and devoid of characteristic forms of topography. In addition, to the west the field lies adjacent to wetlands, and approximately $200 \mathrm{~m}$ to the south of the field there are small ponds filling former clay pits. In the subsoil, below a $0.5 \mathrm{~m}$ thick soil layer, occur silty clays $(1.5 \mathrm{~m}$ thick) and medium sands. In the vicinity of groundwater monitoring wells $\mathrm{Ch}-4$ and $\mathrm{Ch}-5$ was noted a significant thickness of organic soils to a depth of approx. 1.2 $\mathrm{m}$ below the surface.

The Damno site (40 ha) is located near Stupsk city in northern Poland. The study area is located in the zone of a glacial deposit moraine. In the subsoil, below the soil layer, occur silty clays and sandy clays.

The Imielin site (22 ha) is located near Warsaw in central Poland. In the subsoil, below the soil layer, silty clays with a thickness of up to $1 \mathrm{~m}$ have been identified. In the area of groundwater monitoring wells I-3 and I-5, the thickness of this layer reaches up to $2 \mathrm{~m}$. Below occur silty sands and medium sands. To the west, the experimental site is bordered by Gwoździe Lake.

In each of the experimental sites, 6 groundwater monitoring wells were installed using the Edelman sampler. Water samples were collected from the monitoring wells, after stabilization of the groundwater table, into plastic containers $(1.5 \mathrm{~L})$ using a submersible pump. To stabilize the chemical composition of water prior to sample collection, it was necessary to pump three volumes of water stored in the monitoring well. In order to avoid the transfer of pollution, the submersible pump and pipes were washed with distilled water. The frequency of groundwater sampling varied depending on the location (Fig. 1). The depths of the groundwater table are given in brackets in Fig. 1. It should be noted that groundwater monitoring wells D-3 to D-6 were dry. The results of the monitoring studies were analyzed to determine the effects of fertilization on groundwater quality, as well as the depth of the water table and characteristics of the subsoil. 
TABLE I

ELECTRICAL CONDUCTIVITY AND PH OF GROUNDWATER COLLECTED IN THE EXPERIMENTAL SITES

\begin{tabular}{|c|c|c|c|c|c|c|c|c|c|c|c|c|c|c|}
\hline Parameter & Ch-1 & Ch-2 & Ch-3 & Ch-4 & Ch-5 & Ch-6 & D-1 & D-2 & $\mathrm{I}-1$ & $\mathrm{I}-2$ & $\mathrm{I}-3$ & $\mathrm{I}-4$ & $\mathrm{I}-5$ & $\mathrm{I}-6$ \\
\hline Median EC & 699 & 685 & 1,269 & 911 & 678 & 928 & 392 & 428 & 830 & 462 & 552 & 649 & 601 & 431 \\
\hline Mean EC & 931 & 649 & 1,246 & 838 & 662 & 923 & 392 & 428 & 814 & 439 & 502 & 617 & 601 & 431 \\
\hline Median $\mathrm{pH}$ & 8.31 & 7.32 & 7.89 & 7.25 & 7.64 & 7.87 & 7.20 & 7.49 & 7.54 & 8.01 & 8.36 & 8.08 & 7.3 & 6.97 \\
\hline Mean pH & 8.07 & 7.50 & 7.95 & 7.31 & 7.54 & 7.85 & 7.20 & 7.49 & 7.53 & 7.77 & 7.86 & 7.93 & 7.3 & 6.97 \\
\hline
\end{tabular}

\section{B. Chemical analysis}

Electrical conductivity (EC) and $\mathrm{pH}$ were measured in the field immediately after collecting of groundwater samples using a multi-parameter device (SCHOTT, Germany). The water samples were then filtered through a $0.45 \mu \mathrm{m}$ filter, cooled to $2^{\circ} \mathrm{C}$ and transported to the laboratory. In the laboratory, the contents of $\mathrm{PO}_{4}, \mathrm{NH}_{4}, \mathrm{NO}_{3}, \mathrm{NO}_{2}, \mathrm{SO}_{4}$ were measured by the spectrophotometric method using a DR-6000 UV-VIS equipment (Hach Lange, USA), whereas the content of metals $(\mathrm{Cu}, \mathrm{Pb}$ and $\mathrm{Zn})$ was measured by atomic absorption spectroscopy using an iCE-3000 spectrometer (Thermo Scientific, USA). All chemical analyses were made twice and in further calculations were used averaged values. The test results were analyzed using XLSTAT statistical software for Microsoft Excel.

\section{RESULTS AND DISCUSSION}

\section{A. Physical parameters}

The electrical conductivity of the groundwater samples ranges from 350.9 to $1,441.0 \mu \mathrm{S} / \mathrm{cm}$ (Table I). The highest values were observed in samples collected in Chociwel (from 551 to $1,441 \mu \mathrm{S} / \mathrm{cm}$ ), and slightly lower values were noted in Imielin (from 385 to $898 \mu \mathrm{S} / \mathrm{cm}$ ) and Damno (from 351 to 505 $\mu \mathrm{S} / \mathrm{cm}$ ). In Chociwel, the majority of the samples was characterized by EC values exceeding background values (200-700 $\mu \mathrm{S} / \mathrm{cm})$, but not exceeding the values characteristic of Class II of groundwater quality $-2,500 \mu \mathrm{S} / \mathrm{cm}$ [16]. In Imielin, all samples collected from well I-1 and one sample from well I-4 exceed the background value of $700 \mu \mathrm{S} / \mathrm{cm}$, whereas in Damno in both monitoring wells the EC value did not exceed the background values. Measurement of this parameter allows monitoring both water quality and potential migration of contaminants because every change of the substance dissolved in water causes a change in the EC [17]. Some authors suggest that EC values above $1000 \mu \mathrm{S} / \mathrm{cm}$ in shallow groundwater may have resulted from anthropogenic pollution of water [18]. However, in EU countries the maximum admissible value of $\mathrm{EC}$ in potable water is 2,500 $\mu \mathrm{S} / \mathrm{cm}$. This value is also the limit of good groundwater quality.

The $\mathrm{pH}$ of the collected groundwater samples reached values ranging from 6.26 to 8.69 (Table I): in Chociwel from 7.12 to 8.69 , in Damno from 6.26 to 8.13 and in Imielin from 6.79 to 8.38 . With the exception of three samples (collected in September from wells Ch-1 and Ch-3 and in March collected from well D-1), the obtained values were characteristic of background values. In addition, only the $\mathrm{pH}$ of the sample taken in March from well D-1 in Damno was lower than the admissible value for good groundwater quality. According to EU rules, water with a pH ranging from 6.5 to 9.5 is allowed for human consumption.

\section{B. Nitrogen compounds}

The concentration of nitrate in groundwater samples from the analyzed experimental sites ranged from 0.1 to 16.2 $\mathrm{mgNO}_{3} / \mathrm{L}$ (Fig. 2). The largest variability of $\mathrm{NO}_{3}$ concentration was observed in samples taken from monitoring wells located in Chociwel $\left(0.2-16.2 \mathrm{mgNO}_{3} / \mathrm{L}\right)$, but only in one sample the nitrate concentration was characteristic of Class II of groundwater quality $\left(16.2 \mathrm{mgNO}_{3} / \mathrm{L}\right)$. In Imielin, the nitrate concentration ranged from 0.1 to $1.6 \mathrm{mgNO}_{3} / \mathrm{L}$ and therefore was within a range of concentrations typical of background values (0-5 $\left.\mathrm{mgNO}_{3} / \mathrm{L}\right)$. Groundwater in Damno had a concentration of $\mathrm{NO}_{3}$ larger than the background values but still not exceeding the admissible value for Class I of groundwater quality (7.9-9.5 $\left.\mathrm{mgNO}_{3} / \mathrm{L}\right)$. Because of high solubility and anionic form, only to a small extent subject to sorption processes, nitrates are a common form of nitrogen migration in shallow groundwater, especially from fertilization sources [19]. High $\mathrm{NO}_{3}$ concentration $\left(>50 \mathrm{mgNO}_{3} / \mathrm{L}\right)$ has been recorded in numerous aquifers all over the world, e.g. in Canada [20] and Portugal [21]. However, in the case of the experimental sites, no significant anthropogenic effect was observed in the $\mathrm{NO}_{3}$ content and the nitrate concentrations did not exceed the maximum concentrations allowed by EU and WHO in water intended for human consumption and the limit value of good quality of groundwater $\left(50 \mathrm{mgNO}_{3} / \mathrm{L}\right)$.

In the analyzed experimental sites, nitrite concentration ranged from 0.001 to $0.436 \mathrm{mgNO}_{2} / \mathrm{L}$ in groundwater (Fig. 2). The highest values were observed in Chociwel in samples taken in March from wells Ch-1 $\left(0.436 \mathrm{mgNO}_{2} / \mathrm{L}\right)$, Ch-2 $\left(0.333 \mathrm{mgNO}_{2} / \mathrm{L}\right)$ and $\mathrm{Ch}-3\left(0.148 \mathrm{mgNO}_{2} / \mathrm{L}\right)$, and in May from well Ch-6 $\left(0.156 \mathrm{mgNO}_{2} / \mathrm{L}\right)$. All the samples, with the exception of well $\mathrm{Ch}-3$, exceeded the value of the concentration limits for Class II of groundwater quality, but did not exceed the limit value for good groundwater quality $\left(0.5 \mathrm{mgNO}_{2} / \mathrm{L}\right)$. In most samples, the nitrite content in groundwater samples from Chociwel and Imielin did not exceed typical background values $\left(0-0.03 \mathrm{mgNO}_{2} / \mathrm{L}\right)$, whereas the nitrite concentration in the samples collected in Damno was characteristic of Class II of groundwater quality (0.03$0.15 \mathrm{mgNO}_{2} / \mathrm{L}$ ). Some authors assume that the nitrite content above $0.010 \mathrm{mgNO}_{2} / \mathrm{L}$ in the shallow groundwater may be evidence of pollution from e.g. liquid manure or natural and 

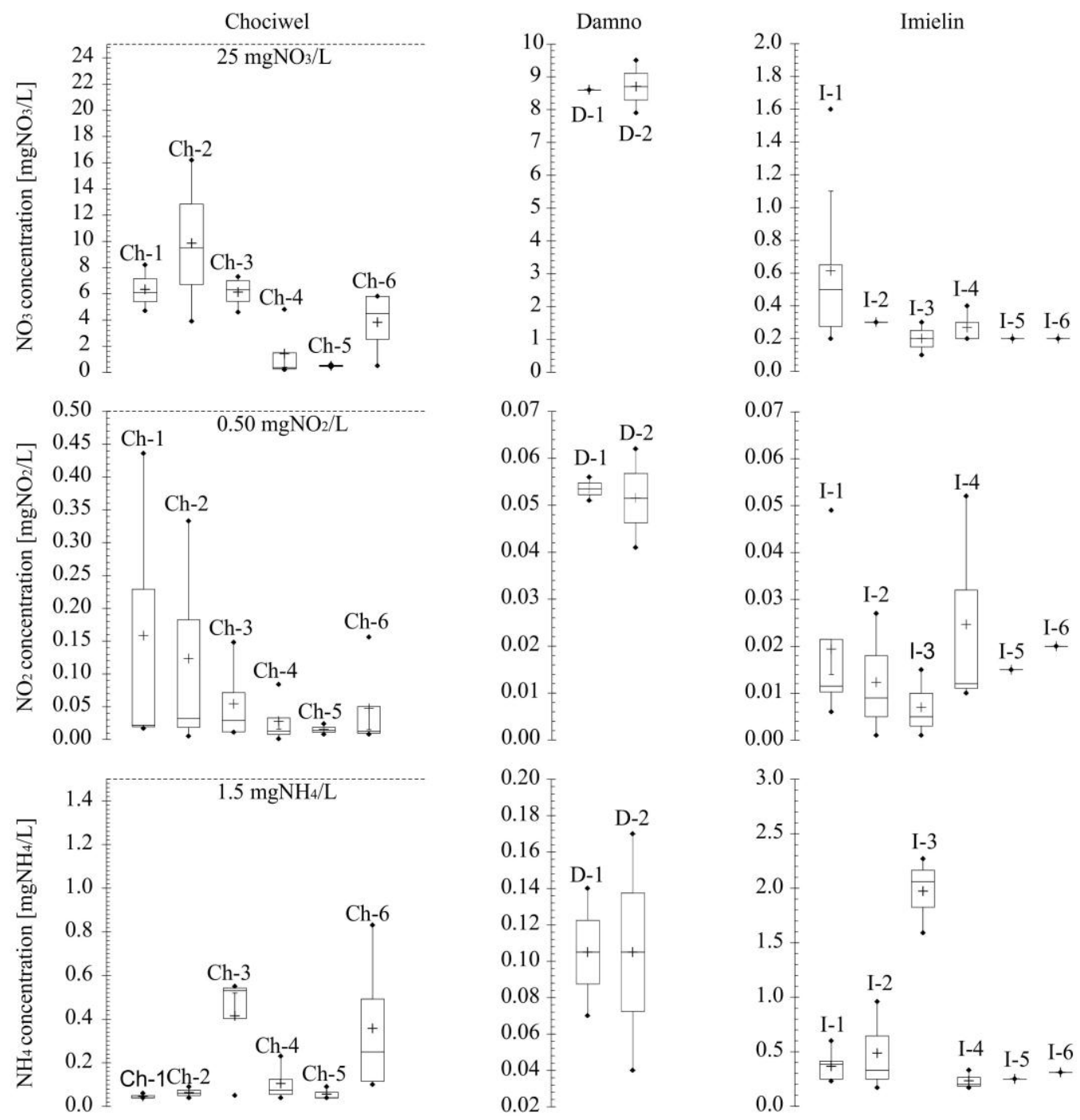

Fig. 2 Concentration of nitrates $\left(\mathrm{NO}_{3}\right)$, nitrites $\left(\mathrm{NO}_{2}\right)$ and ammonium $\left(\mathrm{NH}_{4}\right)$ in groundwater collected in the experimental sites

artificial fertilizers [18]. Furthermore, due to the unstable nature of nitrite, its higher amounts may be an important indicator of water contamination by organic substances. The measured concentrations did not exceed the limit EU values in water intended for human consumption and the limit for good groundwater quality $\left(0.5 \mathrm{mgNO}_{2} / \mathrm{L}\right)$.

It is commonly recognized that ammonium is a typical indicator of pollution, especially in shallow groundwater [22]. The content of ammonium ions in the analyzed groundwater samples ranged from 0.04 to $2.27 \mathrm{mgNH}_{4} / \mathrm{L}$ (Fig. 2). The largest concentrations ranging from 0.17 to $2.27 \mathrm{mgNH}_{4} / \mathrm{L}$ were observed in Imielin, and slightly smaller in Chociwel (0.04-0.83 $\left.\mathrm{mgNH}_{4} / \mathrm{L}\right)$ and Damno (0.04-0.17 $\left.\mathrm{mgNH}_{4} / \mathrm{L}\right)$. Most of the analyzed samples, with the exception of samples taken in Imielin from well I-3, did not show concentrations greater than those typical for the background $\left(0-1 \mathrm{mgNH}_{4} / \mathrm{L}\right)$. Throughout the measuring period, the concentration of ammonium ions in well I-3 exceeded the threshold of good groundwater status $\left(1.5 \quad \mathrm{mgNH}_{4} / \mathrm{L}\right)$ and permissible concentrations in water intended for human consumption $(0.5$ $\mathrm{mgNH}_{4} / \mathrm{L}$ ). Well I-3 is located in a local depression, which also collected organic material such as organic fertilizers. Decomposition of organic matter can be a source of ammonium ions in concentrations characteristic of poor groundwater quality. Maximum concentrations in water intended for human consumption has also been exceeded in wells $\mathrm{Ch}-3$ and $\mathrm{Ch}-6$. However, it must be noted that the migration of ammonium ions in groundwater is inhibited through sorption by the material of the aquifer [22] [23].

\section{C.Phosphates}

The phosphate concentration in the analyzed samples of groundwater ranged from 0.3 to $1.0 \mathrm{mgPO}_{4} / \mathrm{L}$ (Fig. 3.). The highest concentrations were in Chociwel, from 0.3 to 1.0 $\mathrm{mgPO}_{4} / \mathrm{L}$, slightly lower in Damno $\left(0.4\right.$ to $\left.0.7 \mathrm{mgPO}_{4} / \mathrm{L}\right)$ and Imielin ( 0.3 to $\left.0.7 \mathrm{mgPO}_{4} / \mathrm{L}\right)$. The phosphate content in all samples was in the range of concentrations typical of the background $\left(0.01-1.0 \mathrm{mgPO}_{4} / \mathrm{L}\right)$, and did not exceed the threshold of good groundwater quality $\left(1.0 \mathrm{mgPO}_{4} / \mathrm{L}\right)$ but the $\mathrm{PO}_{4}$ concentrations were close to these values. This may be 

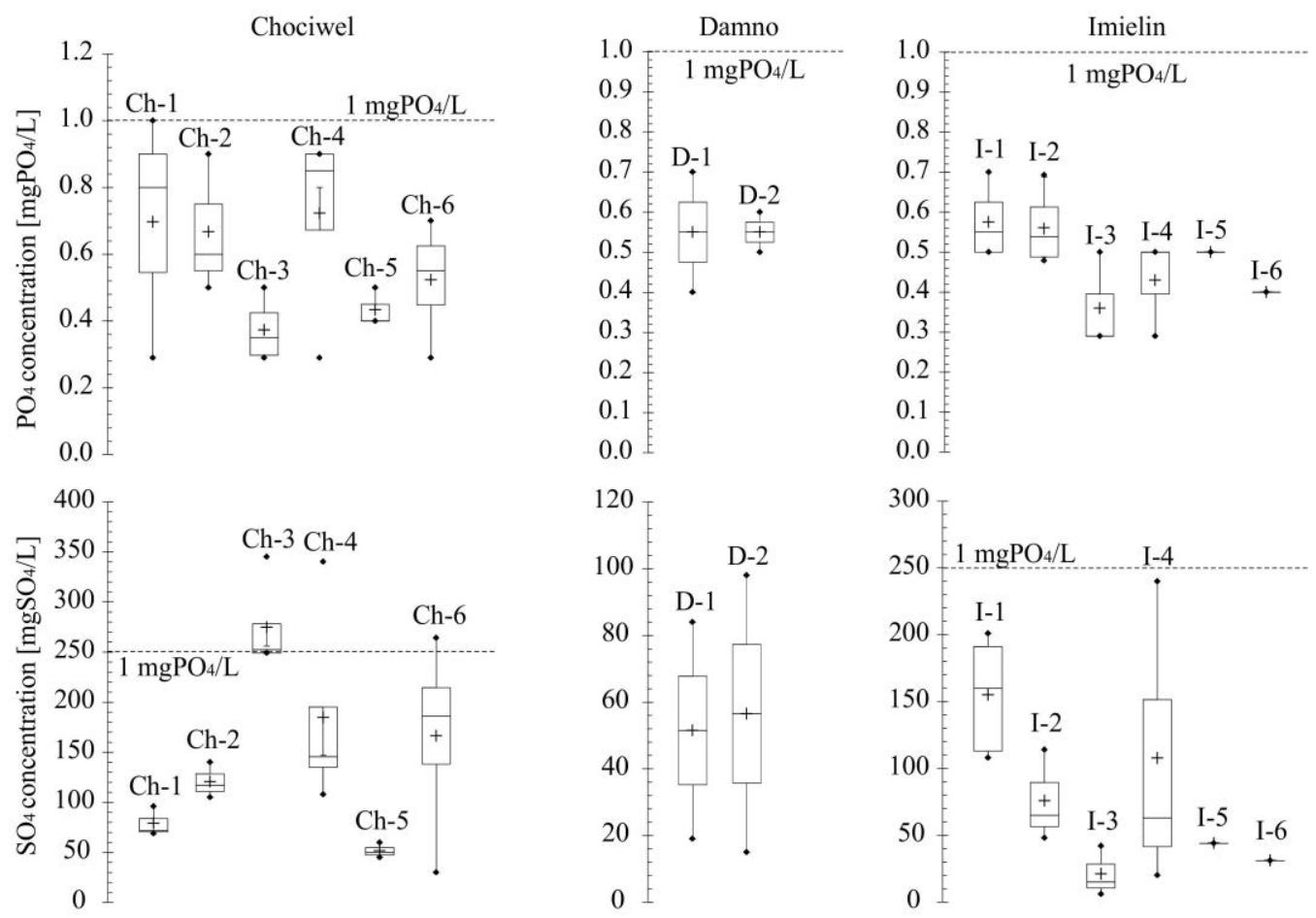

Fig. 3 Concentration of phosphates $\left(\mathrm{PO}_{4}\right)$ and sulphur $\left(\mathrm{SO}_{4}\right)$ in groundwater collected in the experimental sites

due to the inadequacy of the phosphoric fertilizer to the needs of plants. The source of phosphate in groundwater may be fertilization of crop fields. In flat regions, $\mathrm{PO}_{4}$ transport through the soil profile plays a dominant role, which can lead to groundwater eutrophication [24], but according to WHO [25] there are no grounds to limit phosphates in water intended for human consumption.

\section{D.Sulphur}

Sulfate concentration in groundwater samples ranged from 6 to $345 \mathrm{mgSO}_{4} / \mathrm{L}$ (Fig. 3). The highest concentrations were observed in Chociwel (30-345 $\mathrm{mgSO}_{4} / \mathrm{L}$ ). In Damno, $\mathrm{SO}_{4}$ concentration had a value from 15 to $98 \mathrm{mgSO}_{4} / \mathrm{L}$, and in Imielin - from 6 to $240 \quad \mathrm{mgSO}_{4} / \mathrm{L}$. The measured concentrations in most cases were higher than those typical of background values $\left(5-60 \mathrm{mgSO}_{4} / \mathrm{L}\right)$. Similarly as chloride ions, sulfate ions are migrating ions used as the key indicators of pollution from anthropogenic sources to groundwater, which primarily depend on the lack of overlap sorption processes [26]. A sulfate content of less than $250 \mathrm{mgSO}_{4} / \mathrm{L}$ is admissible for water intended for human consumption. In Chociwel, in samples taken from wells Ch-3 and Ch-4 (September), and Ch6 (March), the sulfate concentrations exceeded the threshold values for good groundwater quality $\left(250 \mathrm{mgSO}_{4} / \mathrm{L}\right)$, which most likely was caused by the oxidation of organic sulfur contained in the soil. Higher levels characteristic of the poor quality of groundwater were also reported in Imielin in wells I1 (April) and I-4 (June).

\section{E. Heavy metals}

The zinc concentration in groundwater collected from the analyzed experimental sites was less than $0.0052 \mathrm{mgZn} / \mathrm{L}$, copper - less than $0.021 \mathrm{mgCu} / \mathrm{L}$, and lead - less than 0.05 $\mathrm{mgPb} / \mathrm{L}$. The results indicate that values characteristic of good quality of groundwater have not been exceeded, which are: 1 $\mathrm{mgZn} / \mathrm{L}$ for zinc, $0.2 \mathrm{mgCu} / \mathrm{L}$ for copper, and $0.1 \mathrm{mgPb} / \mathrm{L}$ for lead. In the EU, the permissible concentration of copper in drinking water is $2 \mathrm{mgCu} / \mathrm{L}$, whereas of lead $-0.01 \mathrm{mgPb} / \mathrm{L}$. According to the "Dutch List" popular in Europe, groundwater with a content of less than $0.05 \mathrm{mgZn} / \mathrm{L}, 0.02 \mathrm{mgCu} / \mathrm{L}$ or 0.02 $\mathrm{mgPb} / \mathrm{L}$ is considered to be clean; concentrations exceeding $0.2 \mathrm{mgZn} / \mathrm{L}, 0.05 \mathrm{mgCu} / \mathrm{L}$ or $0.05 \mathrm{mgPb} / \mathrm{L}$ should be indicated for detailed diagnosis, while concentrations of more than 0.8 $\mathrm{mgZn} / \mathrm{L}, 0.2 \mathrm{mgCu} / \mathrm{L}$ or $0.2 \mathrm{mgPb} / \mathrm{L}$ are regarded as requiring pollution prevention and remediation activities.

\section{CONCLUSION}

Analysis of groundwater samples collected from monitoring wells located in the experimental sites has shown that:

1) groundwater collected in spring (wells Ch-3 and Ch-6) and early autumn (wells Ch-3 and Ch-4) in Chociwel should be classified as water of poor quality due to the elevated concentrations of sulfate ions,

2) despite the higher concentrations of phosphates and sulfates, and based on the concentration of all tested parameters, groundwater taken from Damno can be classified as groundwater of good quality,

3) groundwater taken from monitoring wells in Imielin is characterized by lower concentration levels of the analyzed parameters in comparison to the limits for good quality of groundwater. The exception is well I-3 located in a local depression, in which a higher concentration of ammonium ions 
characteristic of poor groundwater quality was measured.

In terms of the content of nitrogen compounds in the groundwater, the samples taken from Chociwel and Damno did not show a worrying state of water quality. The study shows that the applied precision nitrogen fertilization could influence the admissible concentration of nitrates in groundwater, while the inadequacy of the phosphoric fertilizer to the needs of plants could have resulted in the increased concentrations of phosphate in the analyzed groundwater samples.

\section{ACKNOWLEDGMENT}

This research was co-financed by the European Regional Development Fund under the Innovative Economy Operational Programme: BIOPRODUCTS, innovative production technologies of pro-healthy bakery products and pasta with reduced caloric value - POIG.01.03.01-14-041/12.

We thank Hanna Pogonowska, M.Sc. student at the Faculty of Civil and Environmental Engineering WULS, for technical support.

\section{REFERENCES}

[1] J. A. Foley, N. Ramankutty, K. A. Brauman, E. S. Cassidy, J. S. Gerber, M. Johnston, et al., "Solutions for a cultivated planet," Nature, vol. 478, pp. 337-342, Oct. 2011. http://dx.doi.org/10.1038/nature10452

[2] J. Kupiec, A. E. Ławniczak, and J. Zbierska, "Action reducing the outflow ow of nitrates from agricultural sources to waters on the nitrate vulnerable zone in the catchment of the Samica Stęszewska river," Ann. Warsaw Univ. of Life Sci. - SGGW, Land Reclam., vol. 40, pp. 3-13, 2008.

[3] N.N. Rabalais, R.J. Diaz, L.A. Levin, R.E. Turner, D. Gilbert, and J. Zhang, "Dynamics and distribution of natural and human-caused hypoxia," Biogeosciences, vol. 7, pp. 585-619, Feb. 2010. http://dx.doi.org/10.5194/bg-7-585-2010

[4] A. N. Sharpley, L. Bergström, H. Aronsson, M. Bechmann, C. H. Bolster, K. Börling, et al., "Future agriculture with minimized phosphorus losses to waters: research needs and direction," Ambio, vol. 44, pp. 163-179, Feb. 2015. http://dx.doi.org/10.1007/s13280-014-0612-x

[5] A. E. Ulrich, D. F. Malley, and P. D. Watts, "Lake Winnipeg Basin: Advocacy, challenges and progress for sustainable phosphorus and eutrophication control," Sci. Total Environ., vol. 542, pp. 1030-1039, Jan. 2016. http://dx.doi.org/10.1016/j.scitotenv.2015.09.106

[6] CSO (Central Statistical Office of Poland), Means of production in agriculture in the 2013/2014 farming year. Środki produkcji w rolnictwie w roku gospodarczym 2013/2014. CSO CA: Warsaw:2015.

[7] Commission Staff Working Document, Report From The Commission To The Council And The European Parliament on the implementation of Council Directive 91/676/EEC concerning the protection of waters against pollution caused by nitrates from agricultural sources based on Member State reports for the period 2008-2011. European Commission, CA: Brussels, 2013.

[8] B. J. Allred, "Laboratory evaluation of zero valent iron and sulfurmodified iron for agricultural drainage water treatment," Ground Water Monit. Remediat., vol. 32, no. 2, pp. 81-95, 2012. http://dx.doi.org/10.1111/j.1745-6592.2011.01379.x

[9] S.-J. Liu, Z.-Y. Zhao, J. Li, J. Wang, and Y. Qi, "An anaerobic twolayer permeable reactive biobarrier for the remediation of nitratecontaminated groundwater," Water Res., vol. 47, pp. 5977-5985, Jun 2013. http://dx.doi.org/10.1016/j.watres.2013.06.028

[10] J. Fronczyk, and M. Radziemska, "Kinetic studies of copper ions removal from aqueous solutions using various biosorbents filling permeable reactive barriers (PRBs)," Fresen. Environ. Bull., vol. 23, no. 12b, pp. 3384-3390, Dec 2014.
[11] J. Fronczyk, M. Radziemska, and Z. Mazur, "Copper removal from contaminated groundwater using natural and engineered limestone sand in permeable reactive barriers," Fresen. Environ. Bull., vol. 24, no. 1a pp. 228-234, Jan. 2015.

[12] K. Pawluk, J. Fronczyk, and K. Garbulewski, "Reactivity of nano zerovalent iron (nZVI) in permeable reactive barriers (PRBs)," Pol. J. Chem. Technol., vol. 17, no. 1, pp. 7-10, Jan. 2015. http://dx.doi.org/10.1515/pjct-2015-0002

[13] K. Pawluk, and J. Fronczyk, "Evaluation of single and multilayered reactive zones for heavy metals removal from stormwater," Environ. Technol., vol. 36, no. 12, pp. 1576-1583, Dec. 2014. http://dx.doi.org/10.1080/09593330.2014.997299

[14] Directive 2000/60/EC of the European Parliament and of the Council of 23 October 2000 establishing a framework for Community action in the field of water policy (EU Water Directive).

[15] Council Directive 91/676/EEC of 12 December 1991 concerning the protection of waters against pollution caused by nitrates from agricultural sources.

[16] Regulation of the Minister of the Environment dated 23 July 2008 on the criteria and method of evaluating groundwater condition. W sprawie kryteriów i sposobu oceny stanu wód podziemnych (in Polish).

[17] T. Zhang, T. Wang, K. S. Liu, L. Wang, K. Wang, and Y. Zhou, "Effects of different amendments for the reclamation of coastal saline soil on soil nutrient dynamics and electrical conductivity responses," Agr. Water Manage., vol. 159, pp. 115-122, Jun. 2015 http://dx.doi.org/10.1016/j.agwat.2015.06.002.

[18] E. Kellner, J. A. Hubbart, and A. Ikem, "A comparison of forest and agricultural shallow groundwater chemical status a century after land use change," Sci. Total Environ., vol. 529, pp. 82-90, Oct. 2015. http://dx.doi.org/10.1016/j.scitotenv.2015.05.052

[19] E. Pastén-Zapata, R. Ledesma-Ruiz, T. Harter, A. I. Ramírez, and J. Mahlknecht, "Assessment of sources and fate of nitrate in shallow groundwater of an agricultural area by using a multi-tracer approach," Sci. Total Environ., vol. 470-471, pp. 855-864, Feb. 2014. http://dx.doi.org/10.1016/j.scitotenv.2013.10.043

[20] P. Levallois, M. Thériault, J. Rouffignat, S. Tessier, R. Landry, P. Ayotte, et al., "Groundwater contamination by nitrates associated with intensive potato culture in Qúebec," Sci. Total Environ., vol. 217, pp. 91-101, 1998. http://dx.doi.org/10.1016/S0048-9697(98)00191-0

[21] M. P. Mendes, and L. Ribeiro, "Nitrate probability mapping in the northern aquifer alluvial system of the river Tagus (Portugal) using Disjunctive Kriging," Sci. Total Environ., vol. 408, pp. 1021-1034, Feb. 2010. http://dx.doi.org/10.1016/j.scitotenv.2009.10.069

[22] N.N. Dubrovsky, K.R. Burow, G.M. Clark, J.A. Gronberg, P.A. Hamilton, K.J. Hitt, and W.G. Wilber, "The quality of our nation's water - nutrients in the nation's streams and groundwater, 1992-2004," in National Water Quality Assessment Program Circular, vol. 1350, 2010.

[23] J. Fronczyk, and K. Garbulewski, "Evaluation of zeolite-sand mixtures as reactive materials protecting groundwater at waste disposal sites," J. Environ. Sci. China, vol. 25, no. 9, pp. 1764-1772, Dec. 2013. http://dx.doi.org/10.1016/S1001-0742(12)60270-8

[24] W. J. Chardon, and O. F. Schoumans, "Soil texture effects on the transport of phosphorus from agricultural land in river deltas of Northern Belgium, The Netherlands and North-West Germany," Soil Use Manage., vol. 23 (Suppl. 1), pp. 16-24, Aug. 2007. http://dx.doi.org/10.1111/j.1475-2743.2007.00108.x

[25] WHO (World Health Organization), Guidelines for Drinking-Water Quality. World Health Organization, CA: Geneva, 2011.

[26] S. Wu, Z. Chen, M. Braeckevelt, E. M. Seeger, R. Dong, M. Kästner, H., et al., "Dynamics of $\mathrm{Fe}(\mathrm{II})$, sulphur and phosphate in pilot-scale constructed wetlands treating a sulphate-rich chlorinated hydrocarbon contaminated groundwater," Water Res., vol. 46, pp. 1923-1932, Apr. 2012.

http://dx.doi.org/10.1016/j.watres.2012.01.011 